\title{
EFFECT OF DIFFERENT LITTER MATERIALS ON FOOT PAD DERMATITIS, HOCK BURN AND FEATHER COVERAGE IN BROILER CHICKENS ${ }^{1}$
}

\author{
Dušan TERČIČ ${ }^{2}$, Mirjana ŽOLGER ${ }^{3}$, Mojca PESTOTNIK ${ }^{4}$
}

Received November 30, 2015; accepted December 15, 2015. Delo je prispelo 30. novembra 2015, sprejeto 15. decembra 2015.

\begin{abstract}
Effect of different litter materials on foot pad dermatitis, hock burn and feather coverage in broiler chickens

An experiment was conducted to evaluate the feather coverage on breast and thighs in meat type chickens, reared on three different types of litter materials, including wood shavings, shredded paper and chopped wheat straw. The experiment lasted for 72 days. A total of 447 one-day-old meat type chickens were randomly allotted to the three litter materials, giving 149 birds per litter. On days 24, 47 and 72 of the experimental period, feathering on the breast and thighs was scored according to a 1-4 scale. In addition, the severity of foot pad dermatitis (FPD) and hock burn (HB) was evaluated at the same days by attributing scores from 1-3. Litter characteristics (moisture content, water absorbing capacity, bulk density, $\mathrm{pH}$ ) were determined at the end of the experiment. Severity of FPD varied significantly $(\mathrm{P}<0.016)$ among the litter materials with chopped straw showing the highest severity scores and wood shavings showing the lowest. Litter material had no effect ( $\mathrm{P}>0.016)$ on the severity of $\mathrm{HB}$ and on thigh feathering. Birds reared on chopped wheat straw presented the lowest breast feather coverage. Straw litter had the highest moisture content and $\mathrm{pH}$ value. In conclusion, wood shavings proved to be best litter material for meat type chickens rearing among the three tested litter materials.
\end{abstract}

Key words: poultry / broiler chickens / litter / foot pad dermatitis / hock burn / feather coverage
Vpliv različnih vrst nastila na pojav vnetja kože na blazinicah stopal, vnetja kože skočnih sklepov ter na operjenost pri pitovnih piščancih

Poskus je bil zasnovan $\mathrm{z}$ namenom ocenitve operjenosti področja prsi in beder pitovnih piščancev, vzrejenih na treh vrstah nastila, vključujoč lesne oblance, razrezan papir in rezano pšenično slamo. Poskus je trajal 72 dni. Štiristo sedeminštirideset en dan starih pitovnih piščancev je bilo naključno razdeljenih v 3 skupine, 149 živali na posamezno vrsto nastila. V poskusnem obdobju smo trikrat (24., 47. in 72. dan) ocenili operjenost področja prsi in beder $\mathrm{z}$ uporabo lestvice $\mathrm{z}$ ocenami od 1 do 4. Istočasno smo ocenili intenzivnost vnetja kože na blazinicah stopal in intenzivnost vnetja kože na skočnih sklepih $\mathrm{z}$ uporabo lestvice $\mathrm{z}$ ocenami od 1 do 3 . Na koncu poskusa smo vzorcem nastila določili gostoto, vsebnost vode, $\mathrm{pH}$ vrednost ter sposobnost zadrževanja vode. Intenzivnost vnetja kože na blazinicah stopal je bila značilno različna $(\mathrm{p}<0,016)$ med posameznimi vrstami nastila in sicer so najvišje (najslabše) ocene dosegli piščanci, uhlevljeni na rezani pšenični slami, in najnižje (najboljše) piščanci, uhlevljeni na lesnih oblancih. Vrsta nastila ni značilno vplivala $(\mathrm{p}<0,016)$ niti na operjenost področja beder niti na pojavljanje vnetij kože na skočnih sklepih. Pri piščancih, uhlevljenih na pšenični slami, je bila opažena najslabša operjenost področja prsi. Vzorec nastila s pšenično slamo je imel najvišjo vsebnost vode ter najvišjo $\mathrm{pH}$ vrednost. Izmed treh proučevanih materialov so se kot najboljši material za nastiljanje v rejah pitovnih piščancev izkazali lesni oblanci.

Ključne besede: perutnina / pitovni piščanci / nastil / blazinice stopal / skočni sklepi / vnetje kože / operjenost

\footnotetext{
1 This article is part of a Master thesis entitled »The use of different types of litter material for rearing broiler breeders «, issued by Mirjana Žolger, supervisor Assist. Prof Dušan Terčič, Ph. D. / Prispevek je del magistrskega dela Mirjane Žolger z naslovom »Uporaba različnih vrst nastila pri vzreji piščancev kokoši težkega tipa«, mentor doc. dr. Dušan Terčič

2 Univ. of Ljubljana, Biotechnical Fac., Dept. of Animal Science, Groblje 3, SI-1230 Domžale, Slovenia, e-mail: dusan.tercic@bf.uni-lj.si

3 Šmartno pri Slovenj Gradcu 154, SI-2383 Šmartno, Slovenia, e-mail: mikicatayson@gmail.com

4 Same address as 2, e-mail: mojca.pestotnik@bf.uni-lj.si
} 


\section{INTRODUCTION}

Foot pad dermatitis (FPD), hock burn (HB) and breast blisters $(\mathrm{BB})$ are dermatological problems with similar pathologies and are collectively known as a contact dermatitis (Greene et al., 1985). Contact dermatitis is an ulcerative condition of the skin affecting the plantar surface of the feet (FPD), the hock (HB) and the breast (BB) (Haslam et al., 2007). It is seen in growing broiler chickens and turkeys, and in broiler parents. Some lesions are superficial, whereas others progress to deep ulcers and cause discomfort and pain (Cengiz et al., 2011). Besides the negative effect on welfare, different forms of contact dermatitis affect farmer income, and in the future it is likely to have increasing importance in terms of legislation. Several major factors are associated with the occurrence of contact dermatitis including type, depth and condition of litter, stocking density, feed composition, light and climate (Meluzzi and Sirri, 2009).

Of these, litter may be the most important because meat type chickens spend most of their time on the litter and their foot pads, hock and breast are in constant contact with the material on the floor. Therefore, if the type, quantity and quality of litter material are not optimal there is a considerable risk that birds will develop contact dermatitis and breast blisters (Meluzzi and Sirri, 2009). Various types of litter materials are used in different countries. In Slovenia, wood shavings and sawdust are the most common materials used as litter in commercial broiler production. However, these preferred litter materials are becoming limited in supply and expensive. Therefore, appropriate substitutions need to be considered. Various forms of recycled paper and chopped straw have proven to be good litter materials in research and commercial situations. With those idea in view, the present study was designed to evaluate the effects of different litter substrates on feather coverage and on the severity of FPD and HB in meat type chickens.

\section{MATERIAL AND METHODS}

The experiment was carried out at a poultry research station (Biotechnical Faculty, University of Ljubljana, Slovenia) with the approval of the Commission for Animal Experiments of the Institution. Four hundred forty seven newly hatched parent stock chicks of Slovenian traditional meat type breed "Slovenian Late Feathering Hen « were randomly assigned, as mixed sex, to the three litter materials (wood shavings, chopped wheat straw, shredded paper), giving 149 birds per litter (pen). Each group was kept in a pen measuring $30 \mathrm{~m}^{2}$ resulting in a flock density of 5 birds $\mathrm{m}^{-2}$. Experimental pens were located side-by-side within the same environmentally controlled poultry house. Feeder and drinker spaces were identical in each pen. Day old chicks were individually identified by toe clipping. The depth of litter in all pens was approximately $8-10 \mathrm{~cm}$. The brooding temperatures were kept at 32 to $33^{\circ} \mathrm{C}$ from day 1 to 7 ; thereafter, the temperature was reduced by $3{ }^{\circ} \mathrm{C} /$ week until it reached 21 to $23^{\circ} \mathrm{C}$, and was maintained at that temperature thereafter. During the first month, all birds consumed feed for ad libitum intake. From the age of 30 days all birds were fed on restricted rations according to breeder recommendations. The feed was supplied in a single daily feed and was generally consumed in less than 20 minutes. The chickens were given a standard grower feed (11.9 MJ ME/kg, $20.0 \% \mathrm{CP}$ ) containing an anticoccidial additive. Access to water was unlimited. Fresh litter materials were added to pens whenever damp litter resulting from excessive drinking was observed. The photoperiod was $23 \mathrm{~h}$ light (L) and $1 \mathrm{~h}$ dark (D) during the first week. Thereafter, light was decreased by 3 to $4 \mathrm{~h} /$ week to $8 \mathrm{~L}: 16 \mathrm{D}$ at week 8 . The trial lasted 72 days. The severity (i.e., extent of lesions) of FPD and HB and the degree of feathering on the breast and thighs were determined at 24,47 and 72 days. At 24 and 47 days approximately 50-60 birds per pen were randomly chosen, while at 72 days of age all birds were evaluated. The foot pad and hock lesions were assessed using a 3-point scoring system, in which $1=$ no lesions; no or very small superficial lesions, slight discoloration on a limited area, mild thickening of the skin; $2=$ mild lesion; discoloration of the foot pad, superficial lesions, dark papillae; and 3 = severe lesion; ulcers or scabs, signs of haemorrhages or swollen foot pads. The foot pad and hock scores were evaluated by using the mean of both feet. Breast and thighs feathering were scored according to the following 1-4 score scale: $1=$ skin is not visible, given area completely feathered; $2=$ less than $25 \%$ of feathers missing from a given area; $3=25-50 \%$ of feathers missing from a given area; and $4=$ more than $50 \%$ of feathers missing from a given area. At the end of experiment, litter samples were collected from five randomly chosen locations within each pen and thoroughly mixed to obtain material representative of the entire pen. Each litter material was analyzed for moisture content, $\mathrm{pH}$ value and moisture retention capacity. Litter samples were dried at $100{ }^{\circ} \mathrm{C}$ for 18 hours to determine moisture content which is expressed on a fresh matter basis. The $\mathrm{pH}$ of each litter type was measured after litter samples of nearly $10 \mathrm{~g}$ were suspended for $30 \mathrm{~min}$ in $100 \mathrm{~mL}$ of distilled water. $\mathrm{pH}$ was recorded until constant values were obtained. In order to determine water absorbing 
Table 1: Scores of FPD and HB severity and feathering scores on the breast and thighs of meat type chickens reared on different litter materials over 72 days

Preglednica 1: Ocene poškodb kože na blazinicah stopal oziroma na področju skočnih sklepov in ocene operjenosti področja prsi oziroma beder pri pitovnih piščancih, rejenih 72 dni na različnih vrstah nastila

\begin{tabular}{|c|c|c|c|c|c|c|c|c|c|}
\hline \multirow[b]{2}{*}{ Experimental group } & \multirow[b]{2}{*}{$\begin{array}{l}\text { Number of } \\
\text { chickens }\end{array}$} & \multicolumn{2}{|c|}{ FPD scores } & \multicolumn{2}{|c|}{ HB scores } & \multicolumn{2}{|c|}{$\begin{array}{l}\text { Feathering } \\
\text { scores on the } \\
\text { breast }\end{array}$} & \multicolumn{2}{|c|}{$\begin{array}{l}\text { Feathering } \\
\text { scores on the } \\
\text { thighs }\end{array}$} \\
\hline & & $\begin{array}{l}\text { Mean } \\
\text { value }\end{array}$ & $P$ value & $\begin{array}{l}\text { Mean } \\
\text { value }\end{array}$ & $P$ value & $\begin{array}{l}\text { Mean } \\
\text { value }\end{array}$ & $\mathrm{P}$ value & $\begin{array}{l}\text { Mean } \\
\text { value }\end{array}$ & $\mathrm{P}$ value \\
\hline Wood shavings & 243 & $1.00^{\mathrm{a}}$ & 0.0001 & $1.00^{\mathrm{a}}$ & 1.000 & $1.62^{\mathrm{a}}$ & 0.0001 & $1.46^{\mathrm{a}}$ & 0.449 \\
\hline Shredded paper & 254 & $1.15^{\mathrm{b}}$ & & $1.00^{\mathrm{a}}$ & & $1.81^{\mathrm{a}}$ & & $1.50^{\mathrm{a}}$ & \\
\hline Chopped wheat straw & 245 & $1.48^{\mathrm{c}}$ & & $1.00^{\mathrm{a}}$ & & 2.71 & & $1.57^{\mathrm{a}}$ & \\
\hline
\end{tabular}

a,b,c Means followed by the same letters in the same column are not significantly different $(\mathrm{P}>0.016)$

capacity, dried samples of pure litter materials were weighed and placed in pans. Moisture holding capacity was determined by filling the pan with water and letting it stand for 90 minutes. Excess water was then drained for 3 minutes and the sample was then weighed again. The percentage of water absorbed was then calculated on dry matter basis. The results were analysed using the statistical SAS program (SAS Institute, 2008). Ordinal variables (feather scores, foot pad and hock scores) were analyzed using Shapiro-Wilk test to verify the normality of residuals, and Levene test for the homogeneity of variances. Comparisons of the results were done using the Kruskal-Wallis test. When the effects were significant they were tested with the Wilcoxon nonparametric rank test within procedure NPAR1WAY. To counteract the problem of multiple comparisons, all statements of significance for ordinal variables were based upon $\mathrm{P}<0.016$ (Bonferroni correction).

\section{RESULTS AND DISCUSSION}

The severity scores of FPD and $\mathrm{HB}$ and feathering scores on the breast and on the thighs are presented in Table 1.

Wood shavings were ranked as the litter material with the lowest FPD severity. Chopped wheat straw had the worst FPD score (Table 1). It was observed that feathering scores on the breast were significantly $(\mathrm{P}<0.016)$ higher in birds on chopped wheat straw in comparison with birds od shredded paper and wood shavings. The presence of breast blisters was not observed in any experimental group. Feathering scores on the thighs were not affected by the litter materials $(\mathrm{P}>0.016)$.

Initial (at 24 days) and final (at 72 days) FPD scores were similar among birds placed on the shredded paper and chopped straw (Table 2). At 47 days of age, FPD scores were higher $(\mathrm{P}<0.016)$ among birds

Table 2: Effect of litter type on the severity of foot pad dermatitis and hock burn at different ages

Preglednica 2: Vpliv vrste nastila na obseg poškodb kože na blazinicah stopal in kože na področju skočnih sklepov pri različnih starostih

\begin{tabular}{|c|c|c|c|c|c|c|c|}
\hline \multirow[b]{2}{*}{$\begin{array}{l}\text { Age of } \\
\text { chickens }\end{array}$} & \multirow[b]{2}{*}{$\begin{array}{l}\text { Experimental } \\
\text { group }\end{array}$} & \multicolumn{3}{|l|}{ FPD scores } & \multicolumn{3}{|l|}{ HB scores } \\
\hline & & $\begin{array}{l}\text { Number of } \\
\text { animals }\end{array}$ & $\begin{array}{l}\text { Mean } \\
\text { value }\end{array}$ & $P$ value & $\begin{array}{l}\text { Number of } \\
\text { animals }\end{array}$ & $\begin{array}{l}\text { Mean } \\
\text { value }\end{array}$ & $\mathrm{P}$ value \\
\hline \multirow[t]{3}{*}{24 days } & Wood shavings & 55 & 1.00 & 0.0001 & 55 & $1.00^{\mathrm{a}}$ & 1.000 \\
\hline & Shredded paper & 57 & $1.19^{\mathrm{a}}$ & & 57 & $1.00^{\mathrm{a}}$ & \\
\hline & Chopped straw & 52 & $1.32^{\mathrm{a}}$ & & 52 & $1.00^{\mathrm{a}}$ & \\
\hline \multirow[t]{3}{*}{47 days } & Wood shavings & 58 & $1.00^{\mathrm{a}}$ & 0.0001 & 58 & $1.00^{\mathrm{a}}$ & 1.000 \\
\hline & Shredded paper & 58 & $1.36^{\mathrm{b}}$ & & 58 & $1.00^{\mathrm{a}}$ & \\
\hline & Chopped straw & 58 & $2.62^{c}$ & & 58 & $1.00^{\mathrm{a}}$ & \\
\hline \multirow[t]{3}{*}{72 days } & Wood shavings & 130 & 1.00 & 0.032 & 130 & $1.00^{\mathrm{a}}$ & 1.000 \\
\hline & Shredded paper & 139 & $1.05^{\mathrm{a}}$ & & 139 & $1.00^{\mathrm{a}}$ & \\
\hline & Chopped straw & 135 & $1.05^{\mathrm{a}}$ & & 135 & $1.00^{\mathrm{a}}$ & \\
\hline
\end{tabular}

a,b,c Means followed by the same letters in the same column and within the same age are not significantly different $(\mathrm{P}>0.016)$ 
Table 3: Effect of litter type on the feather coverage of the breast and thighs at different ages Preglednica 3: Vpliv vrste nastila na operjenost področja prsi oziroma beder pri različnih starostih

\begin{tabular}{|c|c|c|c|c|c|c|c|}
\hline \multirow[b]{2}{*}{$\begin{array}{l}\text { Age of } \\
\text { chickens }\end{array}$} & \multirow[b]{2}{*}{$\begin{array}{l}\text { Experimental } \\
\text { group }\end{array}$} & \multicolumn{3}{|c|}{ Feathering scores on the breast } & \multicolumn{3}{|c|}{ Feathering scores on the thighs } \\
\hline & & $\begin{array}{l}\text { Number of } \\
\text { animals }\end{array}$ & $\begin{array}{l}\text { Mean } \\
\text { value }\end{array}$ & $\mathrm{P}$ value & $\begin{array}{l}\text { Number of } \\
\text { animals }\end{array}$ & $\begin{array}{l}\text { Mean } \\
\text { value }\end{array}$ & $\mathrm{P}$ value \\
\hline \multirow[t]{3}{*}{24 days } & Wood shavings & 55 & $2.85^{\mathrm{a}}$ & 0.0001 & 55 & $3.07^{\mathrm{a}}$ & 0.0001 \\
\hline & Shredded paper & 57 & $3.57^{\mathrm{b}}$ & & 57 & $3.22^{\mathrm{a}}$ & \\
\hline & Chopped straw & 52 & $3.86^{\mathrm{c}}$ & & 52 & 3.71 & \\
\hline \multirow[t]{3}{*}{47 days } & Wood shavings & 58 & $1.18^{\mathrm{a}}$ & 0.0001 & 58 & $1.00^{\mathrm{a}}$ & 1.000 \\
\hline & Shredded paper & 58 & $1.25^{\mathrm{a}}$ & & 58 & $1.00^{\mathrm{a}}$ & \\
\hline & Chopped straw & 58 & 2.58 & & 58 & $1.00^{\mathrm{a}}$ & \\
\hline \multirow[t]{3}{*}{72 days } & Wood shavings & 130 & $1.30^{\mathrm{a}}$ & 0.0001 & 130 & $1.00^{\mathrm{a}}$ & 0.369 \\
\hline & Shredded paper & 139 & $1.31^{\mathrm{a}}$ & & 139 & $1.00^{\mathrm{a}}$ & \\
\hline & Chopped straw & 135 & 2.31 & & 135 & $1.00^{\mathrm{a}}$ & \\
\hline
\end{tabular}

a,b,c Means followed by the same letters in the same column and within the same age are not significantly different $(\mathrm{P}>0.016)$

raised on chopped straw than those raised on shredded paper. Throughout the whole trial period FPD scores were significantly $(\mathrm{P}<0.016)$ lower in those animals that were placed on wood shavings. Greater values of breast and thighs feather scores were present at 24 days of age. Beyond this age, the values lowered in all experimental groups. This may be attributed to the fact that chicks moult the natal plumage formed in embryonic development into juvenile feathers between 21-35 days of age. Breast feather cover as indicated by feather score was significantly $(\mathrm{P}<0.016)$ better in chicks placed on wood shavings compared with birds placed on chooped straw at every age ( $\mathrm{Ta}$ ble 3). At the ages of 47 days and 72 days all of the evaluated birds achieved a thighs feather score of 1 , or full thighs feather cover. Today reduced feathering is considered beneficial when broilers are reared in hot climates, as it increases heat dissipation; however, it impairs carcass quality (Garcia et al., 2012). Characteristics of litters are summarized in Table 4.

Chopped straw on one hand contained the highest percentage of moisture, on the other hand chicks grown on the chopped straw showed the most severe foot pad lesions. This is not surprising because it is well known that excessive contact with wet and ammoniacal litter is generally considered to be the primary cause of foot and hock burn (Tucker and Walker, 1992). The water holding capacity of litter is a fundamental factor in preserving the foot in a good state (Meluzzi and Sirri, 2009). Foot pad burn scores were lowest in the pen littered with wood shavings. Wood shavings as a litter material with the highest waterholding capacity and consisted of small particles resulted in lower moisture content, minimizing the incidence of lesions in foot pads and breast. Oliveira et al. (2004) found the similar results. Meluzzi et al. (2007) raised birds on chopped straw or wood shavings both in winter and in summer seasons and observed that birds kept on wood shavings exhibited a reduction of $35 \%$ in foot pad dermatitis than those kept on straw (Meluzzi and Sirri, 2009). Tucker and Walker (1992) found lower hock burn scores in birds reared on wood shavings rather than straw, but this effect was not seen in the study of Su et al. (2000).

Table 4: Chemical and physical characteristics of three litter materials Preglednica 4: Kemijske in fizikalne lastnosti treh vrst nastila

\begin{tabular}{lcccc}
\hline & \multicolumn{2}{l}{ Characteristics of litter materials } \\
\cline { 2 - 5 } $\begin{array}{l}\text { Litter material / } \\
\text { Experimental group }\end{array}$ & Moisture content (\%) & $\begin{array}{l}\text { Water absorbing } \\
\text { capacity }(\%)\end{array}$ & Bulk density $\left(\mathrm{kg} / \mathrm{m}^{3}\right)$ & $\begin{array}{l}\text { pH of litter material } \\
\text { at 72 days }\end{array}$ \\
\hline Shredded paper & $9.41 \pm 0.17$ & $37.32 \pm 4.10$ & $350.2 \pm 18.24$ & $8.51 \pm 0.64$ \\
Chopped straw & $21.93 \pm 3.67$ & $56.84 \pm 2.41$ & $368.5 \pm 42.67$ & $9.02 \pm 0.82$ \\
Wood shavings & $7.62 \pm 0.14$ & $86.36 \pm 7.23$ & $317.8 \pm 11.53$ & $8.71 \pm 0.34$ \\
\hline
\end{tabular}

$\mathrm{a}, \mathrm{b}, \mathrm{c}$ Means followed by the same letters in the same column and within the same age are not significantly different $(\mathrm{P}>0.016)$ 


\section{CONCLUSIONS}

From all collected data we can conclude that:

- Of the three litter materials tested, wood shavings showed the lowest FPD severity and the highest feather coverage ob breast, whereas chopped wheat straw showed the highest FPD severity and the lowest feather coverage of breast.

- Type of litter material had no significant effect on $\mathrm{HB}$ and feathering score on the thighs.

- Wood shavings as litter substrate have been found to be better than chopped wheat straw and shredded paper with regard to moisture content and water retention capacity.

\section{REFERENCES}

Cengiz Ö., Hess J.B., Bilgili S.F. 2011. Effect of bedding type and transient wetness on footpad dermatitis in broiler chickens. J. Appl. Poult. Res., 20: 554-560. doi:10.3382/japr.201100368

Garcia R.G., Almeida Paz I.C.L., Caldara F.R., Nääs I.A., Bueno L.G.F., Freitas L.W., Graciano J.D., Sim S. 2012. Litter mate- rials and the incidence of carcass lesions in broilers chickens. Rev. Bras. Cienc. Avic., 14: 27-32

Greene J.A., McCracken R.M., Evans R.T. 1985. A contact dermatitis of broilers - clinical and pathological findings. Avian Pathol., 14: 23-38. doi:10.1080/03079458508436205

Haslam S.M., Knowles T.G., Brown S.N., Wilkins L.J., Kestin S.C., Warriss P.D., Nicol C.J. 2007. Factors affecting the prevalence of foot pad dermatitis, hock burn and breast burn in broiler chicken. Br. Poult. Sci., 48: 264-275. doi:10.1080/00071660701371341

Meluzzi A., Sirri F. 2009. Welfare of broiler chickens. Ital. J. Anim. Sci., 8, Suppl. 1: 161-173. doi:10.4081/ijas.2009. s1.161

SAS INSTITUTE INC. 2008. SAS/STAT User's Guide, Version 9.02. SAS Institute Inc., Cary, NC, USA

Su G., Sorensen P., Kestin S.C. 2000. A note on the effects of perches and litter substrate on leg weakness in broiler chickens. Poult. Sci., 79: 1259-1263. doi:10.1093/ps/79.9.1259

Oliveira M.C., Ferreira H.A., Cancherini L.C. 2004. Efeito de condicionadores químicos sobre a qualidade da cama de frango. Arq. Bras. Med. Vet. Zoo., 56: 536-541. doi:10.1590/ S0102-09352004000400016

Tucker S.A., Walker A.W. 1992. Hock burn in broilers. In: Recent Advances in Animal Nutrition. Garnsworthy P.C., Haresign W., Cole J.D.A. (eds.). Oxford, Butterworth Heinemann: 33-49. doi:10.1016/B978-0-7506-0714-8.50006-0 